\title{
Frequency correlations in grapheme-color synesthesia in Komi-Permyak language
}

\author{
Svetlana S. Shlyakhova
}

DOI: 10.18355/XL.2018.11.02.42

\begin{abstract}
The article deals with preliminary results of experimental research on the colorgraphemic synesthesia of vowels in Komi-Permyak language. The obtained data on Komi-Permyak language is interpreted in the context of data in Russian, English and other Romano-Germanic languages, obtained through analogue research. It is found that the color-graphemic synesthesia of graphons A [a] and $\mathrm{O}[\mathrm{o}]$ presents a universal phenomenon with a high degree of probability. The relative dependence of color associativity of vowels on the initial consonant and the following vowel in color denomination was determined. It was concluded that Komi-Permyak graphons do not have a stable and regular link with colors, the names of which are borrowed. It is possible to assume that letters of the native language are connected with the original color denominations. A tendency of Komi-Permyak vowels, being attracted between chromatic colors (red, blue, yellow), is revealed.
\end{abstract}

Key words: psycholinguistics, phonosemantics, sound symbolism, color-graphemic synesthesia, vowels, Perm languages, Komi-Permyak language, Finno-Ugric languages

\section{Introduction}

Color-graphemic synesthesia was investigated in many languages, and it has a long tradition. Color-graphemic (phonemic) synesthesia is a state, when the visual image of the letter (grapheme) or sound pronunciation, denoted by the letter, induces a definite color sensation (for instance, a letter or sound "a" in Russian linguistic consciousness causes frequently a simultaneous sensation of "red"). The article deals with the term 'graphon', used in Russian linguistics, which includes the features of grapheme, phoneme, letter, and sound in one denomination (Prokofieva, 2008).

The investigation of color-graphemic synesthesia reveals both stable associative links between color and grapheme (Zhuravlev, 1974; Day, 2001; Prokofieva, 2008; Kim et al., 2013), and the factors, influencing these links (Witthoft, Winawer, 2006; Mills et al., 2009; Simner et al., 2005; Beeli et al., 2007; Brang et al., 2011; Watson et al., 2012; Asano, Yokosawa, 2011, 2012, 2013; Rothen et al., 2013; Blair, Berryhill, 2013).

Despite the great variety of languages, which become the material to study the phenomenon of color-graphemic synesthesia, Perm languages stay out of the researchers' sight. Out study is aimed at the revelation of regular and stable links between graphon and color in Komi-Permyak language (refering to Perm branch of Finno-Ugric sub-family of Uralic languages) (Kochetov, Lobanova, 2007).

We have not found any findings of investigations conducted on color-graphemic synesthesia in Permian languages, including the Komi-Permyak one.

The article reveals the results of the experiment, aimed at the revelation of stable and regular associative links between color and graphons of Komi-Permyak language. The obtained data on Komi-Permyak language is interpreted in the context of data in Russian, English and other Romano-Germanic languages, obtained using generally accepted research (Zhuravlev, 1974; Prokofieva, 2008). It is established that the sound-grapheme-color associativity of graphons $\mathrm{A}$ [a] and $\mathrm{O}[\mathrm{o}]$ presents a universal phenomenon with a high degree of probability. Relative dependence of color associativity of Komi-Permyak vowels on the letter-sound composition of color

XLinguae, Volume 11, Issue 2, April 2018, ISSN 1337-8384, eISSN 2453-711X 
denominations has been determined. A tendency of Komi-Permyak vowels, being attracted to chromatic color grade (red, blue), is revealed.

The pronunciation of letters of Komi-Permyak alphabet A [a], Я [ja], У [u], $\ddot{\mathrm{E}}$ [jo], Ö [is pronounced as 'ir' in English girl], i [i], Yu [ju], Y [y], E [je], I [i], O [o], $\mathrm{E}$ [è].

\section{Procedure}

For an obvious reason, a series of experiments was carried out on the individual (the habitants of villages of the Komi-Permyak district) and group (the students of Philological Faculty of the Komi-Permyak Department of the Perm State Humanitarian-Pedagogical University) questionnaire over a span of 5 years, in particular, from 2009 to 2014.

The respondents were suggested a questionnaire with the Komi-Permyak alphabet and a list of color denominations (colored in corresponding color) in Komi-Permyak and Russian languages with graphic distinguishing of Komi-Permyak name: vezh (yellow), gird (red), rud (grey), korichneviy (brown), liz (blue), sid (black), zeleniy (green), and chochkom (white). It was suggested to relate a graphon to the colors from the list, but it was allowed to write the color at the respondent's choice. The additional colors were received: orange, violet, pink, scarlet.

The repeated experiments did not happen to come into any contradiction with the previous one: the increase in a number of informants gradually resulted in strengthening veracity of obtained data. In the numerical expression, it provided the increase by $1-2 \%$, rarely - by $3 \%$, correspondingly.

In the course of the experiment, 186 Komi-Permyaks were interrogated (schoolchildren, students, peasants, and pensioners), aged from 15 to 60 years (with an average age of 37.5 years).

There were obtained 186 inquiry forms, where 6510 reactions were revealed, including $32(0.5 \%)$ refusals, $5631(86.5 \%)$ reactions in Komi-Permyak, and $846(13 \%)$ of reactions in Russian. The inquiry form was in Russian, but the respondents were oriented at the native language.

\section{Results}

Let us consider the results within the interval of $25 \%$ of reactions and above to be consistent results, the ones within the interval from 15 to $24 \%$ to be relatively consistent. Within the confidence interval, there are the graphons, color associativity of which lies within the interval from $9 \%$ to $14 \%$, i.e., exceeds the threshold of random coincidence, but significantly drops behind the absolute mass selection.

The most frequent, regular and stable associative links between color and Komi-Permyak graphons are observed in the spectrum of red and blue colors.

The data on graphons $Я$ [ja] (52\% reactions), A [a] (43\% reactions), and $\mathrm{Y}$ [u] (30\% reactions ) can be considered reliable for red color (the reactions raspberryred and scarlet were also taken into consideration); and relatively reliable - Ë [jo], Ö [as 'ir' in English girl], Ю [ju], Ы [y], Е [je], И [i], О [o] (correspondingly, 15-23\% of reactions).

A tendency towards attraction between practically all vowels to the spectrum of red color in the consciousness of Komi-Permyaks is obvious. The same tendency is also observed in the spectrum of blue color. The data on graphons $\mathrm{[ju]}$ (33\% reactions) and Ы [y] (26\% reactions) can be considered to refer to blue color (the reactions sky-blue, violet and turquoise were also taken into consideration). High degree of conformity is observed for the vowels E [je] (21\%) - Э [è] (19\%); O [o] (19\%) - Ё [jo] (21\%); И (21\%) - i [i] (18\%, correspondingly,).

There is no reliable data on yellow spectrum. The data on the graphons $\mathrm{E}$ [je] $(20 \%)-Э$ [è] $(20 \%)$; i [i] $(15 \%)$ can be considered relatively reliable. High 
degree of conformity is observed for the vowels E [je] (20\%) - Э [è] (20\%); Ю [ju] $(13 \%)-\mathrm{y}[\mathrm{u}](14 \%)$.

The coloristics for black and white colors does not produce any satisfactory results. The data on the graphons b [y] (16\%), and i [i] (16\%) can be considered relatively reliable for black color.

The data on the graphons A [a] (17\%), O [o] (23\%) can be considered relatively reliable for white color.

The coloristics for grey, green, orange and brown colors does not produce any satisfactory results. There has not been established a stable connection between the Komi-Permyak graphons and grey $(r u d)$, green, orange, and brown colors. The data on orange $\mathrm{O}[\mathrm{o}]$ (18\% reactions) and green $\mathrm{E}$ [jo] (17\%) can be considered relatively reliable.

In Komi-Permyak language, color denomination pyd (rud) is perceived both as grey and carrot (fox) colors. There are no denominations of brown color in KomiPermyak language: there is a denomination of "earth color" in Komi-Permyak language, and the color denomination of korichneviy (brown) was borrowed from Russian. In the villages, the habitants refused not only to determine the link of graphon and brown color but even to link the brown color with any notion. The color denominations of zeleniy (green), and oranzheviy (orange) also present Russian borrowings.

As a result of data reduction, the matrix of sound-graphemic-color associativity for the vowels of Komi-Permyak language was compiled (Table 1). One and the same graphon in different lines of the table demonstrates the multiplicity of its color evaluation by the respondents. Relatively reliable data (15-24\% of reactions) is denoted in normal font, and reliable results (from $25 \%$ and above) are shown in semibold.

Table 1: A matrix of graphemic-color associativity of the Komi-Permyak vowels

\begin{tabular}{|c|c|}
\hline Color & Komi-Permyak graphons \\
\hline BEZH (yellow) & $\mathrm{i}[\mathrm{i}], \mathrm{E}$ [je], Э [è] \\
\hline GIRD (red) & $\begin{array}{c}\text { Ы [y], О [o], И [i], Е [je], i [i], Ö } \\
\text { [as i in English girl], Ю [ju], Ё } \\
\text { [jo], } \mathbf{y ~ [ u ] , ~}, \text { [ja], A [a] }\end{array}$ \\
\hline RUD (grey) & - \\
\hline KORICHNEVIY (brown) & - \\
\hline LIZ (blue) & $\begin{array}{c}\text { У [u], О [o], И [i], Е [je], Э [è], i } \\
\text { [i], } \\
\text { Ö [as i in English girl], Ë [jo], } \\
\text { Ы [y], Ю [ju] }\end{array}$ \\
\hline SID (black) & Ы [y], i [i] \\
\hline ZELENIY (green) & Ë [jo] \\
\hline CHOCHKOM (white) & $\mathrm{A}[\mathrm{a}], \mathrm{O}[\mathrm{o}]$ \\
\hline ORANZHEVIY (orange) & $\mathrm{O}[\mathrm{o}]$ \\
\hline
\end{tabular}

Thus, the reliable results (see Figure 1) are obtained for four vowels of Komi-Permyak language ( $\mathrm{Y}[\mathrm{u}]$, Я [ja], A [a] for red color, and $\mathrm{b} \mathrm{[y],} \mathrm{Ю} \mathrm{[ju]} \mathrm{for} \mathrm{blue}$ color), color associativity of which lies within the significant vowels (from $25 \%$ to $52 \%$ reactions), quote, "it is they that constitute the nationally-conditioned matrix", unquote (Prokofieva, 2008). 


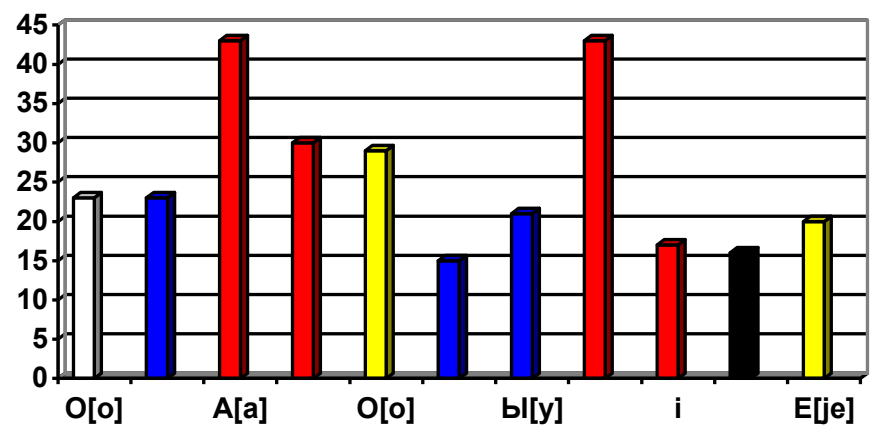

\section{Figure 1: A matrix is the dominant of graphemic-color associativity of the Komi- Permyak vowels}

\section{Discussion}

\subsection{Factors influencing the color-graphemic synesthesia}

At present, the leading factors, influencing the sound-grapheme-color associativity, still stay blurred. The researchers mention a lot of reasons for colorgraphemic synesthesia: visual shape of grapheme (Brang et al., 2011; Watson et al., 2012); sound (Asano and Yokosawa, 2011, 2012); essence or meaning of the notions, which the graphon is connected with (Rich et al., 2005; Asano and Yokosawa, 2012); grapheme frequency (Beeli et al., 2007); color denomination, i.e., the order of letters in the color name (Cytowic, 1989; Motluk, 1997; Witthoft, Winawer 2006; Watson et al., 2012); memory, for instance, toys, containing colorful letters, magnets on a refrigerator, etc. (Witthoft and Winawer, 2006, 2013); a complex of enumerated factors (Asano and Yokosawa, 2011, 2012; Watson et al., 2012).

Let us consider the factors, influencing the color-graphemic synesthesia in Komi-Permyak language.

\subsection{Features of speech sound}

It is impossible to correlate clearly expressed color distinguishing characteristic of vowels with characteristics of sounds, denoted by letters. There is a tendency observed for the spectrum of blue to correlate with high vowels, and the spectrum of yellow to correlate with mid vowels. The spectrum of red is typical for high and low vowels.

\subsection{Grapheme leading role}

It is noted that, when determining colors of letters/sounds, a grapheme plays the leading role (Cytowic, 1989; Motluk, 1997; Witthoft, Winawer 2006), as the color associativity frequently depends on the initial consonant and following vowel in color denomination. However, this tendency is not absolute for Russian and English languages (Prokofieva, 2008). This tendency is not proved to be observed in KomiPermyaks bilinguals for native and Russian languages for red (gird), black (sid), white, and yellow (vezh) colors.

It is possible to assume the influence of initial and following letters in color denomination on coloristics, thus, $\mathrm{O}[\mathrm{o}]$ for white (чочком-chochkom), or orange (оранжевӧй-oranzheviy), and E [je] for yellow (веж-vеzh). However, this consistent pattern is not observed in qualification of A [a], Я [ja] for red (гӧрд-gird), Ы [y], Ю [ju] for blue (лӧз-liz), А [a] for white (чочком-chochkom), and Ы [y], i [i] for black (cböd-sid). 


\section{4. $\quad$ Grapheme and phoneme}

Some experiments (Day, 2001) prove that color perception of a grapheme and a sound differs insignificantly: a tendency towards attraction between one and another color is preserved.

In our experiment, insignificant differences in perception of a phoneme and a grapheme are shown by high consistency of reactions per the graphons E [je] (20\%) - Э [è] (20\%); Ю [ju] $(13 \%)-\mathrm{Y}$ [u] (14\%) for yellow color; E [je] $(21 \%)$ - Э [è] (19\%); О [o] (19\%) - $\ddot{\mathrm{E}}$ [jo] (21\%); И [i] (21\%) - i [i] (18\%) for blue spectrum.

\subsection{The influence of bilingualism}

As the Komi-Permyaks are historically bilinguals and speak Russian fluently, it is possible to assume the impact of the Russian language on the soundgrapheme-color associativity of Komi-Permyaks. Let us compare the obtained results (Table 2) on Komi-Permyak language with the data on Russian and English languages (Prokofieva, 2008).

Table 2: A matrix of color-graphemic associativity of the Komi-Permyak, Russian, and English vowels

\begin{tabular}{|c|c|c|c|}
\hline Color & Komi-Permyak & Russian & English \\
\hline $\begin{array}{c}\text { Komi-Permyak веж(vezh) } \\
\text { Russian желтый(zheltiy) } \\
\text { English yellow } \\
\end{array}$ & $\begin{array}{c}\mathbf{O}[\mathrm{o}], \underline{\mathrm{i}}[\mathrm{i}], \underline{\mathrm{E}} \\
{[\mathrm{je}], \underline{\underline{\exists}}[\mathrm{e}]}\end{array}$ & $\begin{array}{c}\underline{E}[j e], \ddot{E} \\
{[j o], \mathbf{O}[\mathrm{o}],} \\
\underline{\underline{\boldsymbol{y}}[\mathrm{è}]}\end{array}$ & $\underline{\mathbf{E} Y}$ \\
\hline $\begin{array}{c}\text { Komi-Permyak гӧрд } \\
\text { Russian красный } \\
\text { English red }\end{array}$ & 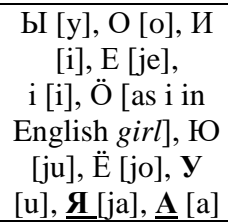 & $\begin{array}{c}\underline{\mathbf{A}}[\mathrm{a}], \mathbf{~} \\
{[\mathrm{ju}], \underline{\boldsymbol{g}}[\mathrm{ja}]}\end{array}$ & $\underline{\mathbf{A}}$ \\
\hline $\begin{array}{c}\text { Komi-Permyak pyd } \\
\text { Russian cepbiü } \\
\text { English grey }\end{array}$ & - & - & - \\
\hline $\begin{array}{l}\text { Komi-Permyak коричневӧй } \\
\text { Russian коричневый } \\
\text { English brown }\end{array}$ & - & Ы [y] & - \\
\hline $\begin{array}{c}\text { Komi-Permyak лӧз } \\
\text { Russian синий } \\
\text { English blue }\end{array}$ & $\begin{array}{c}\underline{\mathrm{y}}[\mathrm{u}], \mathrm{O}[\mathrm{o}], \underline{\mathrm{U}} \\
\text { [i], E [je], } \\
\ni \text { [è], i [i], Ö [as } \\
\text { i in English girl], } \\
\ddot{\mathrm{E}} \text { [jo], } \\
\text { Ы [y], Ю [ju] }\end{array}$ & $\begin{array}{l}\underline{\boldsymbol{И}}[\mathrm{i}], \underline{\mathrm{y}} \\
{[\mathrm{u}],} \\
\underline{\mathrm{O}}[\mathrm{ju}]\end{array}$ & $\underline{\mathbf{U}}$ \\
\hline $\begin{array}{c}\text { Komi-Permyak сьӧд } \\
\text { Russian черный } \\
\text { English black }\end{array}$ & b [y], i [i] & $\underline{\underline{\mathbf{b}}[\mathrm{y}]}$ & - \\
\hline $\begin{array}{l}\text { Komi-Permyak зелёнӧй } \\
\text { Russian зеленый } \\
\text { English green }\end{array}$ & $\underline{\ddot{E}[j o]}$ & $\begin{array}{l}\underline{\mathbf{E}}[\mathrm{je}], \underline{\mathbf{E}} \\
{[\underline{\mathrm{jo}}], \mathbf{y}[\mathrm{u}]} \\
\underline{\underline{\partial}}[\mathrm{è}]\end{array}$ & $\underline{\mathbf{E}}$ \\
\hline $\begin{array}{c}\text { Komi-Permyak чочком } \\
\text { Russian бельй } \\
\text { English white }\end{array}$ & $\underline{\mathrm{A}}[\mathrm{a}], \underline{\mathrm{O}}[\mathrm{o}]$ & $\underset{[\mathrm{o}]}{\mathrm{A}[\mathrm{a}], \underline{\mathbf{O}}}$ & I $\underline{\mathbf{O}}$ \\
\hline $\begin{array}{c}\text { Komi-Permyak оранжевӧй } \\
\text { Russian оранжевый } \\
\text { English } \text { orange }\end{array}$ & $\underline{\mathrm{O}[\mathrm{o}]}$ & - & $\underline{\mathrm{O}}$ \\
\hline
\end{tabular}

XLinguae, Volume 11, Issue 2, April 2018, ISSN 1337-8384, eISSN 2453-711X 
The comparison of data on Komi-Permyak, Russian (supposed impact on the synesthesia), and English languages shows that the impact of bilingualism on the sound-grapheme-color associativity is not determinative. In whole, the data on KomiPermyak language coincides with the results, obtained in Russian and English languages (they are underlined in the Table 2; Figure 2).

Besides, the argument for the hypothesis about the insignificant impact of bilingualism on the sound-grapheme-color associativity is that the Komi-Permyak graphons do not have a stable and regular link with colors, the names of which are borrowed from Russian (green, orange, brown). This fact allows us to presume that there is a correlation between "native" letters and original color denominations.

\subsection{Universality and specificity}

According to E. Sepir and S. Tsuru, color associations of consonants are nationally conditioned, and the phonosemantic potential of vowels allows referring their associativity to universal phenomena (Sepir, 1993; Tsuru, 1933). The data on English, Russian (Prokofieva, 2008), and Komi-Permyak languages do not prove this statement.

Let us compare the data on Komi-Permyak vowels with the data obtained from materials on Russian (Zhuravlev, 1974; Prokofyev, 2008), English (Hollingworth, Weischer, 1939; Prokofieva, 2008), and Romano-Germanic (Day 2001) languages.

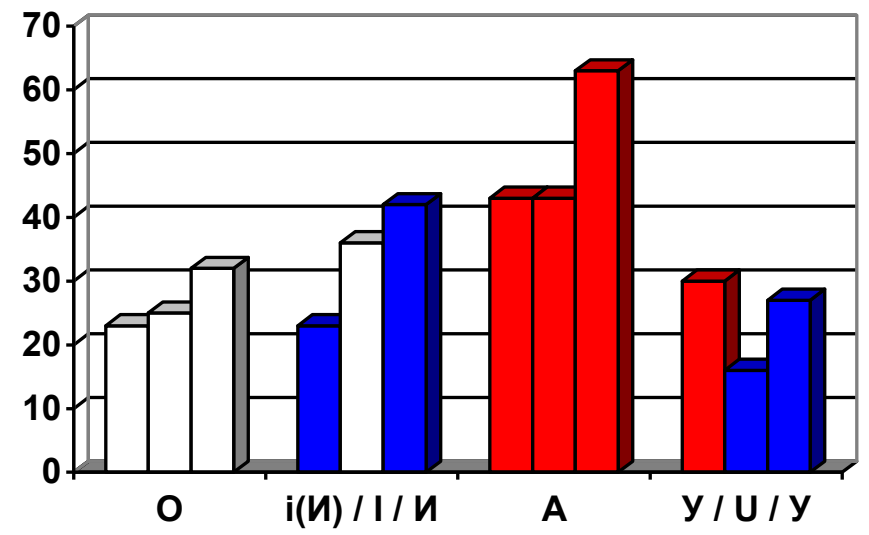

Figure 2: A matrix of color- graphemic associativity of the Komi-Permyak (column 1), English (2nd column), and Russian (column 3) vowels

The evaluations for the graphon A [a] coincide in all languages in the red spectrum (Romano-Germanic - 44\%; English - 43\%; Russian - 63\%; Komi-Permyak $-45 \%)$; they partially coincide with the graphon $\mathrm{O}[\mathrm{o}]$ in white and yellow areas (Romano-Germanic - 56\% (white) and 8\% (yellow); English - 25\% (white) and 11\% (yellow); Russian $-35 \%$ (white) and 38\% (yellow); Komi-Permyak - 23\% (white) and $24 \%$ (yellow).

It is not approved, quote, "to search for coincidences of other graphons, due to articulatory differences in pronounced sounds and positional interchanges", unquote, (Prokofieva, 2008), that requires further research.

It is possible to assume that sound-color associativity of the graphons $\mathrm{A}$ [a] and $\mathrm{O}$ [o] with a high degree of probability presents a universal phenomenon, as the associativity of the rest vowels is nationally conditioned, that requires further research. Thus, specific Komi-Permyak graphons i [i] and Ö [pronounced as 'ir' in 
English girl], not existing in Russian, therefore, being not the subject to the impact of bilingualism, do not clearly express color.

\subsection{Presence of color name in language}

Our experiments show that the Komi-Permyak graphons do not have the stable and regular links with colors, the names of which are borrowed from Russian (green, orange, brown). This fact allows us to presume that there is a link between "native" letters and original color denominations.

At materials on 98 languages, B. Berlin and P. Kay (Berlin, Kay, 1969) showed that the system of color denominations passed seven stages in its development. At the stage I, the language lexically distinguishes two colors: black, involving dark tones, and white, involving all light tones. The category "red" appears at the stage II, and it involves all tones of red, orange, yellow, brown, pink and violet. Yellow and green are distinguished at the stage III, and the "white" and "black" categories perception narrows. At the stages III and IV, there can be two variants of development, as yellow and green appear one after another randomly, but not simultaneously.

The rule of the evolution of color denomination, according to B. Berlin and P. Kay, is as follows: if a language has color denominations at a definite stage of its development, it is proved to have all color denominations of the previous stages. Thus, if a language distinguishes the category "blue", there are also prior names for white, red, green, and yellow colors duly established.

Komi-Permyak language has six main color denominations: гӧp $($ gird) for 'red', liz for 'blue', sid for 'black', chochkom for 'white', vezh for 'yellow', and rud for 'grey'.

In the evolution of color terminology in languages, according to B. Berlin and P. Kay, formation of color denomination of blue (stage V) follows yellow and green (III-IV stages). Psychological experiments also point at this, presuming that when distinguishing a green square, the reaction time of Russians and KomiPermyaks is practically the same, but, distinguishing a blue square, Komi-Permyaks spend much more time than Russians (Goncharov, Knyazev, 2010).

In Komi-Permyak language, there appears to be "the failure" of the evolutionary scheme: Komi-Permyak language has лӧз (liz) for 'blue' color denomination (V stage), and pyd (rud) - for grey (VII stage) colors, but there are no names for green (III-IV stages), and brown (VI stage) colors. It complies with the theory of B. Berlin and P. Kay, where some exceptions were mentioned.

As per calculations by ethno linguists, there are no more than $5 \%$ of all languages (predominantly of Slavonic group) in the world, where blue and sky-blue have self-designation. At the same time, in many languages, the whole range of green and blue is denoted by one color, and there exist much more names for a range of the warm red-yellow color.

This tendency is clearly observed in Komi-Permyak language: there is a range of green and blue color of indivisible character (the lack of Komi-Permyak denomination for green), but with the existence of warm yellow and red color denomination. At present, there are no definite terms to denote orange, pink and violet colors.

Despite radical differences in a verbal mark of color intervals, people of different cultures perceive colors similarly, i.e., they tend to distinguish the same focal colors. There are distinguished easily named (e.g., red, green, and blue), and hardly named colors, without definite names for them to be denoted in language.

Thus, it is reasonable for us to assume that the easily named (identified) basic colors (formedness of color denominations in language) have a greater degree of coincidence, less degree of coincidence in the evaluation of graphons color in KomiPermyak language is connected with peculiarities of a color picture of the KomiPermyak world.

XLinguae, Volume 11, Issue 2, April 2018, ISSN 1337-8384, eISSN 2453-711X 
In vocalism, it is also possible to assume that there is a mythological impact on sound-grapheme-color associativity in Komi-Permyak language. The obtained data allows us to presume that there is an attraction between Komi-Permyak vowels and chromatic colors (red, yellow, blue), which are the symbols of the middle world in the culture, whereas achromatic colors, symbolizing top (white) and bottom (black) worlds, are not associated with vowels.

Namely, the world of people is presented in obvious colors, generalized in yellow, blue, and red colors, which dominate in Komi-Permyak culture. The green color in Komi-Permyak culture was not endued with special meaning, only in the end of the XX century, a special color denomination of green began to appear. It is pointed out by the fact, that Komi-Permyak denomination of green was borrowed from Russian language, i.e., зеленӧй (zeleniy).

It is possible that, quote, "not all graphemes in the language have the similar associative possibilities, and that it is connected with the peculiarities of human brain activity rather than the language peculiarities", unquote, (Prokofieva, 2008, p. 215).

\section{Conclusion}

Our experiment produced satisfactory results on five vowels of the KomiPermyak language, namely, У [u], Я [ja], А [a] for red color, and Ы [y], Ю [ju] - for blue color, which color associativity is presented in obtained numbers (from $25 \%$ to $52 \%$ of reactions, correspondingly).

As per our findings, the color characteristic of vowels in the Komi-Permyak language does not have any direct link with the characteristics of sounds, denoted by letters.

The data of our experiment reveals that there is the relative dependence of color associativity of vowels on the initial consonant and the following vowel in color denomination.

We have found out that high conformity of reactions to separate graphons in the spectrums yellow and blue colors points insignificance of differences in color perception of a phoneme and a grapheme.

In near-core and peripheral areas, Komi-Permyak vowels prove to have the same characteristics, common for the Indo-European languages. The evaluations of the graphon A [a] coincide with the spectrum of red color; they partially coincide with the graphon $\mathrm{O}[\mathrm{o}]$ in the spectrums of white and yellow colors.

It is possible to assume that color associativity of the graphons $\mathrm{A}$ [a] and $\mathrm{O}$ [o] with a high degree of probability presents a universal phenomenon, whereas associativity of the rest of the vowels is nationally predetermined, requiring further research.

At the same time, our experiments prove that Komi-Permyak graphons do not have the stable and regular link with colors, the names of which are borrowed (green, orange, and brown). This fact allows us to presume that there is a link between "native" letters and the original color denominations.

We also assume the mythological impact on sound-grapheme-color associativity in Komi-Permyak language. The tendency of Komi-Permyak vowels towards the spectrum of chromatic colors (red, blue, and yellow) is reasonably obvious, but their brightness and saturation turn out to be erased, blurred, pale, as compared to the Russian language.

The preliminary data obtained on the Komi-Permyak language requires further research. It is important to specify the factors which influence associativity of graphons, including mythology, and the surrounding environment. These problems require additional investigations. 


\section{Bibliographic references}

ASANO, M. - YOKOSAWA, K. 2011. Synesthetic colors are elicited by sound quality in Japanese synesthetes. Conscious. Cogn., vol. 20, pp. 1816-1823.

ASANO, M. - YOKOSAWA, K. 2012. Synesthetic colors for Japanese late acquired graphemes. Conscious. Cogn., vol. 21, pp. 983-993.

ASANO, M. - YOKOSAWA, K. 2013. Grapheme learning and color- graphemic synesthesia: toward a comprehensive model of grapheme-color association. Front. Hum. Neurosci, vol. 7, pp. 757.

BEELI, G. - ESSLEN, M. - JÄNCKE, L. 2007. Frequency correlates in colorgraphemic synesthesia. Psychol. Sci., vol. 18, pp. 788-792.

BERLIN, B. - KAY, P. 1969. Basic Color Terms. Their Universality and Evolution, Berkeley and Los Angeles: University of California Press.

BLAIR, C.D. - BERRYHILL, M.E. 2013. Synesthetic grapheme-color percepts exist for newly encountered Hebrew, Devanagari, Armenian and Cyrillic graphemes. Consciousness and Cognition, vol. 22, n. 3, pp. 944-954.

BRANG, D. - ROUW, R. - RAMACHANDRAN, V. S. - COULSON, S. 2011. Similarly shaped letters evoke similar colors in color-graphemic synesthesia. Neuropsychologia, vol. 49, pp. 1355-1358.

CYTOWIC, R. 1989. The Man who Tasted Shapes. New York. Putnam.

DAY, S. 2001. Trends in Synesthetically Colored Graphemes and Phonemes. Available online: http://www.daysyn.com/Day2004Trends.pdf

GONCHAROV, O.A. - KNYAZEV, N.N. 2010. Linguistic determination of perception of colors in Russian and Komi, Psychological Journal of International University of Nature, Society and Man "Dubna", vol. 2. Available online: http://www.psyanima.ru/journal/2010/2/2010n2a1/2010n2a1.pdf

HOLLINGWORTH, H.L. - WEISCHER, V. 1939. Presistent alphabetical synesthesia. American Journal of Psychology, vol. 12, pp. 361-366.

KIM, S. - BLAKE, R. - KIM, C.-Y. 2013. Is " $\Sigma$ " purple or green? Bistable colorgraphemic synesthesia induced by ambiguous characters. Consciousness and Cognition, vol. 22, n. 3, pp. 955-964.

KOCHETOV, A. - LOBANOVA, A. 2007. Komi-Permyak coronal obstruents: Acoustic contrasts and positional variation. Journal of the International Phonetic Association, vol. 37, n. 1, pp. 51-82.

MILLS, C. B. - METZGER, S. R. - FOSTER, C. A. - VALENTINE-GRESKO, M. N. - RICKETTS, S. 2009. Development of color-graphemic synesthesia and its effect on mathematical operations. Perception, vol. 38, pp. 591-605.

MOTLUK, A. 1997. Two Synesthetes Talking Colour. Synesthesia. Cambridge, MA: Blackwell.

PROKOFIEVA, L.P. 2008. Sound-color associativity in language consciousness and literary text: universal, national, individual aspects. PhD thesis. Saratov.

ROTHEN, N. - TSAKANIKOS, E. - MEIER, B. - WARD, J. 2013. Coloured Letters and Numbers (CLaN): A reliable factor-analysis based on synesthesia questionnaire. Consciousness and Cognition, vol. 22, n. 3, pp. 1047-1060.

SEPIR, E. 1993. A study in phonetic symbolism. Edward Sapir. Selected Papers on linguistics and cultural studies. M.: Progress Universe.

SIMNER, J. - WARD, J. - LANZ, M. - JANSARI, A. - NOONAN, K. - GLOVER, L. 2005. Non-random associations of graphemes to colours in synesthetic and nonsynesthetic populations. Cogn. Neuropsycho, vol. 22, pp. 1069-1085.

TSURU, S. - FRIES, H.S. 1933. Sound and meaning. Journal of General Psychology, vol. 8, pp. 281-284.

WATSON, M. R. - AKINS, K. A. - ENNS, J. T. 2012. Second-order mappings in color-graphemic synesthesia. Psychon. Bull. Rev., vol. 19, pp. 211-217.

WITTHOFT, N. - WINAWER, J. 2006. Synesthetic Colors Determined by Having Colored Refrigerator Magnets in Childhood. Cortex, vol. 42, n. 2, pp. 175-183.

XLinguae, Volume 11, Issue 2, April 2018, ISSN 1337-8384, eISSN 2453-711X 
ZHURAVLEV, A.P. 1974. Phonetic value. L.: LSU.

Words: 4209

Characters: 27453 (15,25 standard pages)

Svetlana S. Shlyakhova

Doctor of Sc., Philology (Dr. habil.)

Head of the Department of foreign languages, advertising and public relations

Perm National Research Polytechnic University

Chernyshevskogo Street 23-102

Perm,

Russia

shlyahova@rambler.ru 